\title{
咀嚼運動に関する臨床的研究
}

\author{
一食品の大きさ・固さの影響について一
}

瑞森 崇弘 桑原 隆男 西尾 公一

宮内 修平 丸山 剛郎

\section{Clinical Studies on Chewing Movements}

-Effects of Foods size and Hardness-

Takahiro Mizumori, Takao Kuwahara, Koichi Nishio,

Shuhei Miyauchi and Takao Maruyama

\section{I. 緒 言}

下颚運動に関しては，古くから種々の研究がなされて いるが，われわれは下䫛運動の中でも重要な機能的運動 であり，上位中枢と顎口腔系諸器官との協調による咀鮁 運動に着目している.この生理的な運動の実態を把握す るために生体機能への干涉が最小限にとどめられた測定 装置として Sirognathographを用い,さらにこれをパ ーソナル・コンピュータと組合せて下頡運動解析システ ムSirognathograph Analysing System ${ }^{1,2)}$ を完成した. このシステムの目的は, 下顎運動, 特に咀礵運動の分析 を行い顎口腔系機能異常の診断を行うことにあり, 現 在, 正常者および機能異常者のデータの蓄積を行ってい る.

咀緭運動, 特に運動経路の研究はすでに多く行われて いるが3 34), いかなる要因により咀緭運動のどの 部 分 が変化するのか, あるいは咀緭運動に変化がみられた場 合，それは何に起因するものなのかを論じた研究は少な く, 咀嚼運動を診断の基準として用いる際の問題点とな っている.

筆者らは，咀嚼運動を機能的測面から解析するため に，顎口腔系に異なる機能対象，すなわち性状の異なる 食品を与えた場合に, どのような咀徱運動の変化が現れ

大阪大学歯学部歯科補緅学第一講座

Osaka University Faculty of Dentistry 1 st Department of Prosthetic Dentistry

昭和 60 年 4 月 30 日受付
るかをみることにより, 顎口腔系の機能内容・機能機序 の一端を探ることを試みた.

\section{II. 方 法}

被験者には, 本学学生から, 顎関節部に雑音・疼痛等 症状がなく，歯列不正や補緅物の少ない，年齡 23〜26 歳の男子 6 名を選んだ.

被験食品としては, タクアンとガムを用いた. タクア ンは, 小・中・大の大きさの被験食品として用いるため に，一辺の長さがそれぞれ $12,15,18 \mathrm{~mm}$ の立方体とな るように切り，咀嚼開始から鮼下までを測定した，ガム は固さによる影響をみるために, ソフト・ガム, ハード・ ガムの 2 種類を用いた. ソフト・ガムは安定した咀嚼運 動を発生させると考えられ，臨床的な応用にも使用 ${ }^{35)} し$ ており，今回は他の食品に対する比較基準ともした.

データ収集は Sirognathograph Analysing System に より,リアルタイム・ディスプレイで咀嚼運動の表示を 行いながら，サンプリング周期 $10 \mathrm{msec}$ で行った. 実 験は, 被験者の習慣性咀嚼側について行った. タクアン の小・中・大 (以下 $\mathrm{S} \cdot \mathrm{M} \cdot \mathrm{L}$ と略す), ソフト・ガム, ハード・ガムをそれぞれ 1 回ずつ測定し，これを断続的 に 3 回くり返した. 図 1 は, ソフト・ガム咀緭の 1 例を プロッタで描記したものである.

タクアンは, 咀嚼が進行するにつれ運動経路が変化す ると考えられたので，咀㘊開始から嚥下までのストロー ク数を 3 等分し, 咀嚼初期 · 中期・末期について検討し た. ガムについては, 安定した食品形状として用いるた 


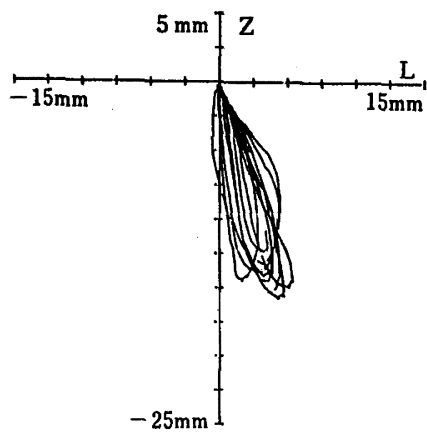

Frontal

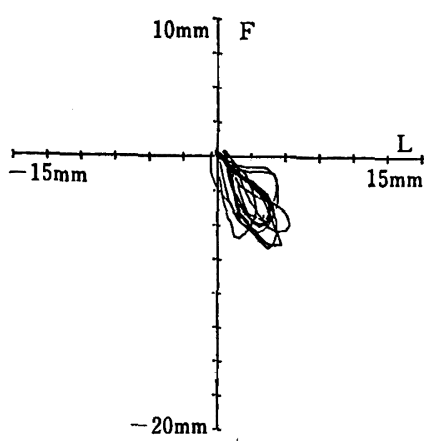

Horizontal [OTN09204.SG]

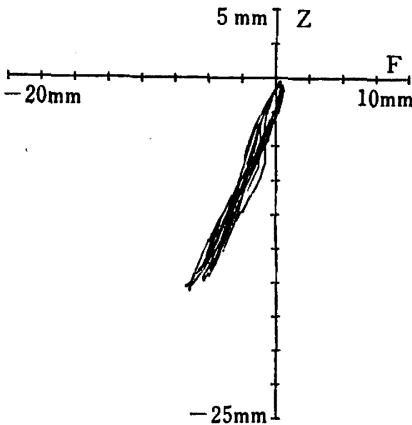

Sagittal

图 1 ソフトガム咀嚼のプロッタ出力例

表 1 垂直的開口量の 1 被験者での比率の計算例

\begin{tabular}{l|ccc|c|c}
\hline \hline & $\begin{array}{c}\text { 1st day } \\
(\mathrm{mm})\end{array}$ & $\begin{array}{c}\text { 2nd day } \\
(\mathrm{mm})\end{array}$ & $\begin{array}{c}\text { 3rd day } \\
(\mathrm{mm})\end{array}$ & $\begin{array}{c}\text { mean } \\
(\mathrm{mm})\end{array}$ & $\begin{array}{c}\text { ratio } \\
(\%)\end{array}$ \\
\hline $\mathrm{S}$ 初期 & 14.0 & 14.2 & 13.8 & 13.8 & 112.2 \\
M 初期 & 14.8 & 14.9 & 14.8 & 14.8 & 120.3 \\
L 初期 & 16.2 & 17.2 & 16.4 & 16.6 & 135.0 \\
Hard & 15.0 & 15.0 & 13.2 & 14.4 & 117.1 \\
Soft & 12.8 & 12.3 & 11.9 & 12.3 & 100.0 \\
\hline
\end{tabular}

S, M, L はタクアンの小・中・大を,

Hard, Soft は八ード・ガムソフト・ガムをそれぞれ表す

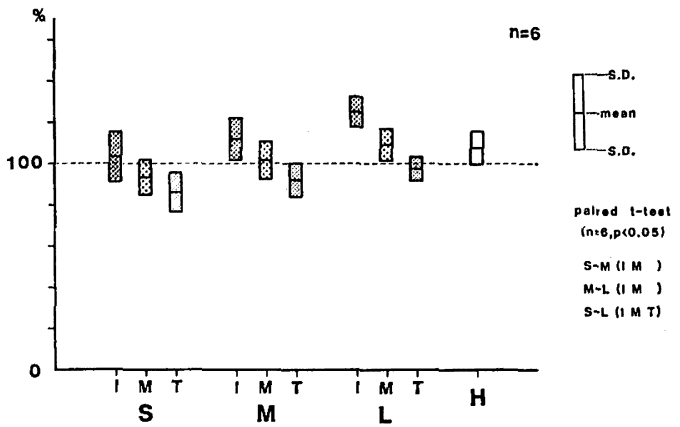

図 2 開口量のソフトガム咀嚼に対する比較

表 2 垂直的開口量の比率の 6 被験者での平均と標準偏差の計算例（単位：\%）

\begin{tabular}{lcrrrrr|rc}
\hline 被験者 & 1 & 2 & 3 & \multicolumn{1}{c}{4} & \multicolumn{1}{c}{5} & \multicolumn{1}{c|}{6} & 平均 & 標準偏差 \\
\hline S 初期 & 112.2 & 102.7 & 114.3 & 80.8 & 100.7 & 109.1 & 103.3 & 12.2 \\
M 初期 & 120.3 & 114.3 & 118.0 & 99.4 & 98.5 & 120.7 & 111.9 & 10.3 \\
L 初期 & 135.0 & 126.5 & 131.6 & 119.2 & 116.0 & 122.6 & 125.2 & 7.3 \\
Hard & 117.1 & 103.4 & 105.3 & 114.1 & 94.9 & 111.5 & 107.7 & 8.1 \\
\hline
\end{tabular}

めに軟化した後に約 20 秒閒の測定を行い，測定開始か ら 5 秒後よりの 10 ストロークを用いた.

咀嚼運動を数值的に評価するため, Sirognathograph Analysing System により平均咀嚼経路を算出し，閉口 路の垂直的開ロレベル $0.5,1.0,1.5,2.0,4.0,6.0,8.0$, $10.0 \mathrm{~mm}$ における平均の側方偏位量を得た. また重直的 開口量の中央值，咬合相時間 - 開口相時間 · 閉口相時 間・咀嚼周期も得た.

各被験者の測定值は 3 日間で平均した. 食品の大き さ・固さの影響をみるため,ソフト・ガム咀嚼を基準と する比率を各被験者ごとに計算し，全被験者での平均お
よび標準偏差を算出した．垂值的開口量の中央值につい ての 1 被験者での比率の計算例を表 1 に，6被験者での 平均と標準偏差の計算例を表 2 に示す.

また， 6 人の正常機能者に共通する特徵をみるため各 被験者の 3 日間での平均值について, 同じ咀嚼時期での $\mathrm{S}$ と $\mathrm{M}, \mathrm{M}$ と $\mathrm{L}, \mathrm{S}$ と $\mathrm{L}$ また, ソフト・ガムとハー ド・ガム等の組データとし， $5 \%$ の有意水淮で $\mathrm{t}$-検定を 行った. 


\section{III. 結 果}

垂直的開口量の中央值についての計算結果を図 2 のグ ラフに示す. $\mathrm{S} \cdot \mathrm{M} \cdot \mathrm{L}$ はタクアンの小・中・大を， $\mathrm{I} \cdot \mathrm{M} \cdot \mathrm{T}$ は咀嚼の初期 (initial stage) $\cdot$ 中期 (middle stage)・末期（terminal stage）をそれぞれ表している.
H はハード・ガムである. ソフト・ガムは基準值の 100\%であるため, グラフには表していない. タクアン では，咀嚼が進行していくにつれ開口量が減少していく 様子が現れている.

一方, 3 日間の測定値の平均值について, 各被験者で 組データとし， $5 \%$ の有意水準で $\mathrm{t}$-検定したところ, 咀 嚼初期と中期では, SM 間, ML 間, SL 間のすべてに有

表 3 垂直的開口量についての結果

\begin{tabular}{|c|c|c|c|c|c|c|c|c|c|c|c|}
\hline \multirow{2}{*}{ 被験者 } & \multicolumn{3}{|c|}{ 初期 } & \multicolumn{3}{|c|}{ 中期 } & \multicolumn{3}{|c|}{ 末期 } & \multirow[t]{2}{*}{ Soft } & \multirow[t]{2}{*}{ Hard } \\
\hline & $\mathrm{S}$ & M & $\mathrm{L}$ & S & $\mathrm{M}$ & $\mathrm{L}$ & $\mathrm{S}$ & M & $\mathrm{L}$ & & \\
\hline 1 & 13.8 & 14.8 & 16.6 & 12.2 & 13.6 & 13.7 & 11.7 & 11.9 & 11.7 & 12.3 & 14.4 \\
\hline 2 & 15.1 & 16.8 & 18.6 & 13.3 & 14.5 & 16.0 & 12.0 & 12.9 & 14.1 & 14.7 & 15.2 \\
\hline 3 & 15.2 & 15.7 & 17.5 & 13.1 & 13.8 & 14.9 & 10.3 & 12.6 & 12.3 & 13.3 & 14.0 \\
\hline 4 & 12.6 & 15.5 & 18.6 & 13.0 & 15.1 & 17.3 & 12.7 & 14.0 & 16.3 & 15.6 & 17.8 \\
\hline 5 & 13.8 & 13.5 & 15.9 & 11.5 & 12.0 & 12.9 & 10.9 & 10.9 & 12.6 & 13.7 & 13.0 \\
\hline 6 & 22.7 & 25.1 & 25.5 & 21.6 & 23.3 & 24.4 & 21.0 & 21.5 & 21.8 & 20.8 & 23.2 \\
\hline
\end{tabular}

しいは組データの $\mathrm{t}$ 一検定 $(\mathrm{n}=6, \mathrm{p}<0.05)$ で有意差のあった組合せを示す

(単位mm)

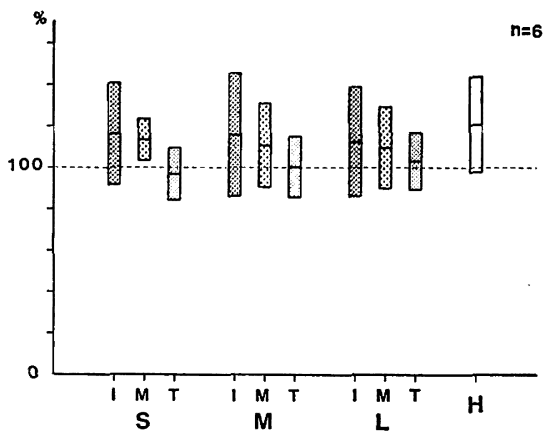

(1) 開ロレベル $1.0 \mathrm{~mm}$

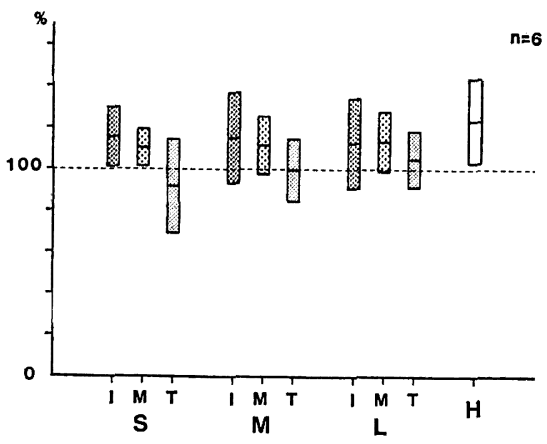

(2) 開ロレベル $2.0 \mathrm{~mm}$

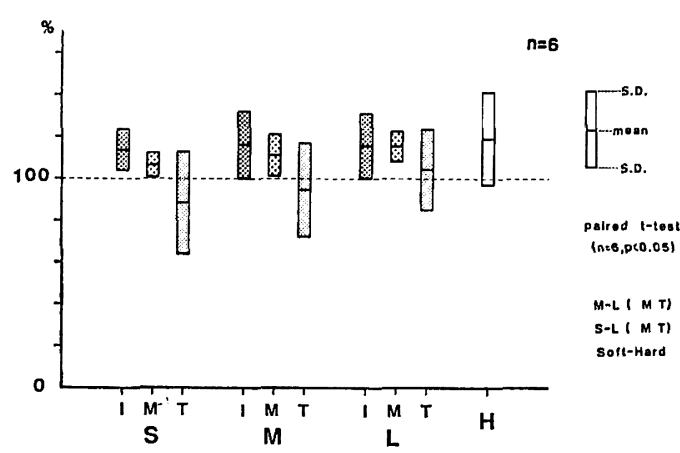

(3) 開ロレベル $4.0 \mathrm{~mm}$

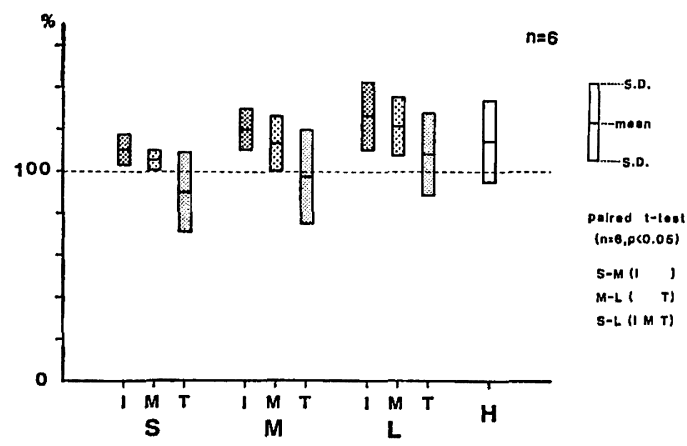

(4) 開ロレベル $8.0 \mathrm{~mm}$

図 3 開口路の側方偏位量のソフトガム咀嚼に対する比較 
意差が認められた. 咀嚼の末期では, SL 間にのみ有意 差があった. また, ソフト・ガムーハード・ガム間に差 を認めなかった．以上の結果を表 3 に示す．この結果か
ら, 開口量は食品の大きさに左右され, 咀嚼の進行とも 関係していることが推察される. また, 食品の固さは, 大きさ程には開口量に影響を及ぼしていない。

表 4 組データの $\mathrm{t}$-検定の結果

（表中の初期等は, 有意差の現れた時期あるいは開ロレベルを示す）

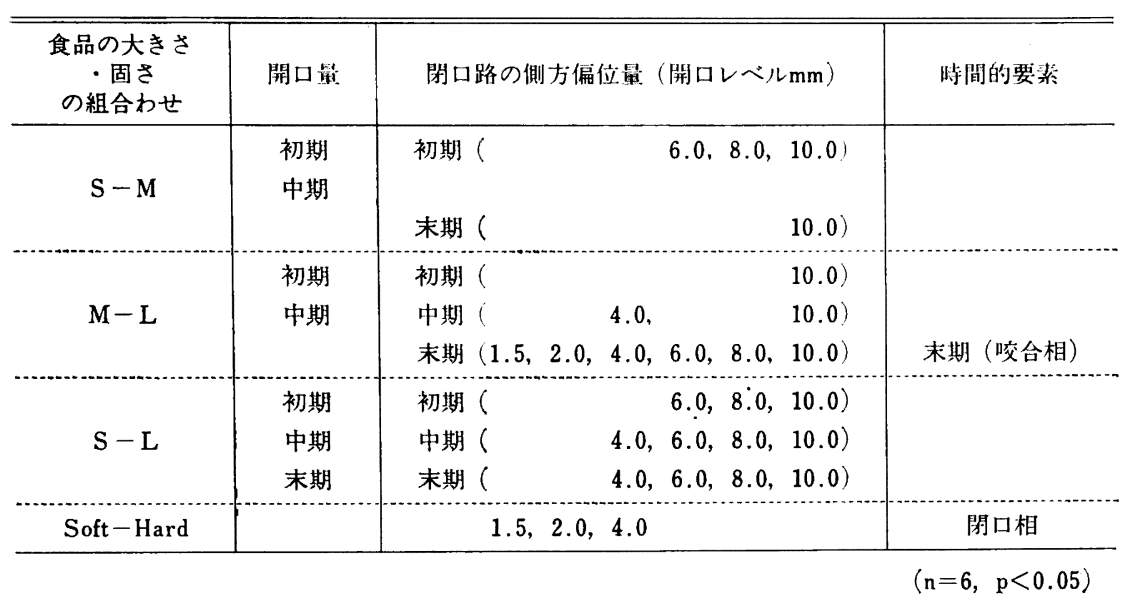

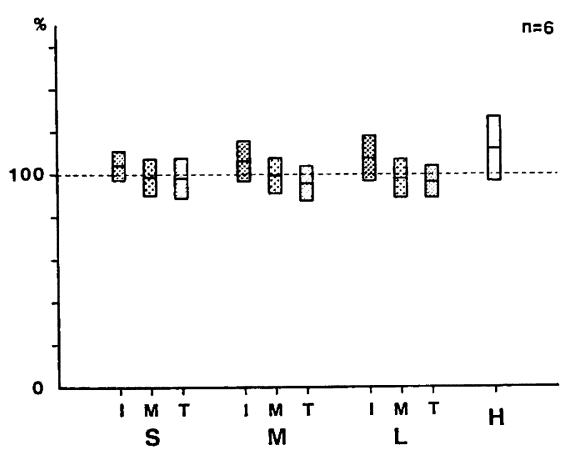

図 4 咀㘄周期のソフトガム咀嚼に対する比較

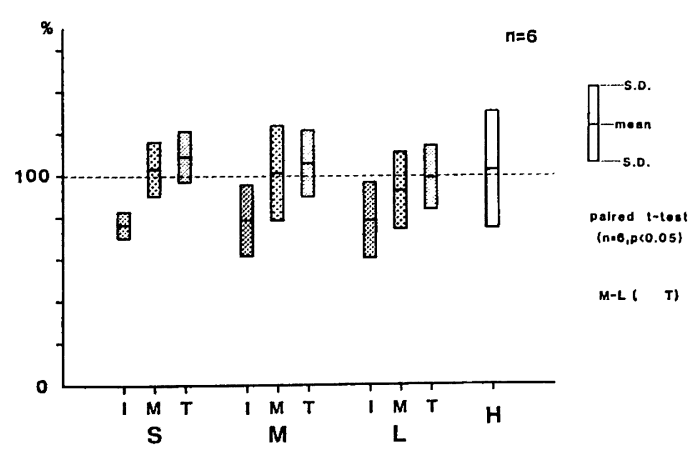

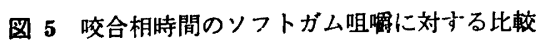

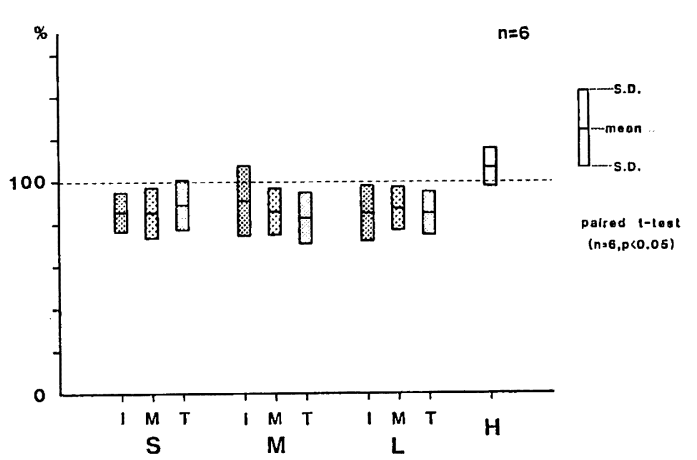

図 6 開口相時間のソフトガム咀嚼に対する比較

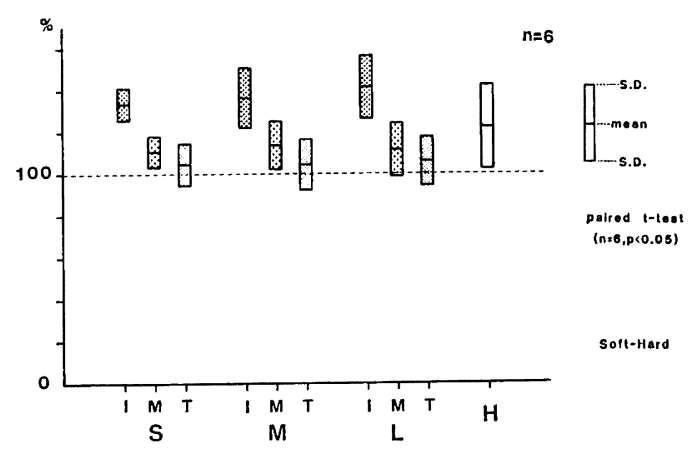

图 7 開口相洔間のソフトガム咀霹に対する比較 
$90-1066$

補釉誌

つぎに, $0.5,1.0,1.5,2.0,4.0,6.0,8.0,10.0 \mathrm{~mm}$ の 各垂直的開口レベルにおける，閉口路の側方偏位量につ いて, 同様のグラフ化および $\mathrm{t}$-検定を行った. 開ロレべ ル 1.0, 2.0,4.0,8.0 mm についてのグラフを図 3 (1) (4)に示す. 組データの $\mathrm{t}$-検定の結果は表 4 にまとめた. $0.5 \mathrm{~mm}$ および $1.0 \mathrm{~mm}$ のレベルでは, $\mathrm{SM}$ 間, $\mathrm{ML}$ 間, SL 間, ソフト・ガムーハード・ガム間のいずれに も有意差はみられなかった.

$1.5 \mathrm{~mm}$ および $2.0 \mathrm{~mm}$ のレベルでは，小・中・大に ついては，末期の ML 間でのみ差があった. このレべ ルで, ソフト・ガムーハード・ガム間に有意差を認め た.

$4.0 \mathrm{~mm}$ レベルでは，中期および末期での ML 間, SL 間に差を認めた。咀嚼初期では差はみられなかった。こ のレベルでもソフト・ガムーハード・ガム間に有意差を 認めた.

$6.0 \mathrm{~mm}$ および $8.0 \mathrm{~mm}$ レベルでは, $\mathrm{SM}$ 間に初期で, ML 間に後期で, SL 間に初期・中期・後期で，それぞれ 差を認めた. ソフト・ガムーハード・ガム間には有意差 がみられなかった。

$10.0 \mathrm{~mm}$ レベルになると, 食品の大きさについては, 中期の SM 間以外のすべての時期について有意差が現 れた. 固さについては有意差はみられなかった.

以上の結果から, 閉口路の側方偏位量に対して, 食品 の大きさは $4.0 \mathrm{~mm}$ 以上のレベルで影響を与え, 食品の 固さは $1.5,2.0,4.0 \mathrm{~mm}$ レベルで影響を現すことが分 った.

同様に咀嚼周期，咬合相時間，開口相時間，閉口相時 間についてもグラフ化と組データの $\mathrm{t}$-検定を行った (図 4〜7, 表 4).

咀嚼周期については, 有意差はみられず, 食品の大き さ・固さによらずほぼ一定の値を示していた.

咬合相時間は咀嚼の進行で変化したが，同時期では食 品の大きさに関して有意差は後期の ML 間でみられた のみであった. ソフト・ガムーハード・ガム間にも有意 差はなかった.

開口相時間はタクアン咀嗄では大きさ・時期によらず ほぼ一定で, 有意差はなかった. ソフト・ガムーハード・ ガム間にも有意差はなかった.

閉口相時間は咀嚼の進行により短縮していくょうだ が，同時期での比較では有意差はみられなかった. しか し，ソフト・ガムーハード・ガム間には有意差が認めら れた.

以上により，食品の大きさは，同じ咀獣時期では咀緭
29 巻 5 号 (1985)

のリズム的な要素にはあまり影響を与えず，食品の固さ は閉口相時間に影響するといえよう。

\section{IV. 考察}

咀徱運動を決定する要因として, 被験者に関するも の, 食品に関するもの, さらに被験者と食品との関係に 関するものの 3 つ大大きく分類できる. 表 5 にこれらを 列挙した.

この要因すべてについて同時に考究することは困難で あるので, 被験者としては, 臨床的に正常とみなされる 者を選び，各被験者での諸要因は可能な限り一定とし た. 環境についても，十分予備実験をくり返し被験者に 慣れさせた後，本実験を開始した．また，被験食品の要 因としては，大きさと固さについてのみをとりあげ研究 した.

咀嚼とは，食物を摂取してからこれを食塊にして瞙下 するまでに口腔, 咽頭中で行われるすべての生理的過程 と定義されている ${ }^{36)}$. よって, 咀嚼運動の研 究の中に は, 咀嚼運動経路のみでなく, 燕下されるまでの時間的 経過の追求も含まれるべきである.しかし，特に運動経 路の研究には，等質な経路を発生させると思われるチュ ーイング・ガムを用いるのがよいと考え, 固さの異なる 2 種類のガムを用いて，食品の固さの影響をみた。一方， 大きさを規定しやすいタクアンにより, 食品の大きさの 影響と咀嚼の時期に関した咀噯運動の変化をみた.

計測項目として，垂直的開口量・閉口路の側方 偏位 量 - 咀嚼周期 - 咬合相時間 - 開口相時間 - 閉口相時間を 取り上げた. 閉口路の側方偏位量については, 0.5, 1.0, $1.5,2.0,4.0,6.0,8.0,10.0 \mathrm{~mm}$ レベルについて分析を 行った.

食品の大きさ，固さが咀嚼運動に与える影響をみるた め, 各被験者のソフト・ガム咀鮁での値を基準とした, 小・中・大のタクアン咀嚼の各咀徱時期およびハード . ガム咀礵時の比率を算出, グラフ化した. また， 6 人の 正常被験者に共通する特徴をみるため, 日をかえて 3 回 測定を行い, この平均值を被験者の当該食品に対する代 表値とし, 組データの $\mathrm{t}$-検定を行った.

・食品の大きさに関して

有意差はまず開口量に現れていた，大きい食品に対し て，これを上下歯列間に位置させるために，小さい食品 よりも開口量を増加することが必要と考えられる.

さらに, 有意差は, $4.0 \mathrm{~mm}$ レベル以上での開口路側 方偏位量に現れた. ある開口度以上では, 開口量の増加 
表 5 咀嚼運動を決定する要因

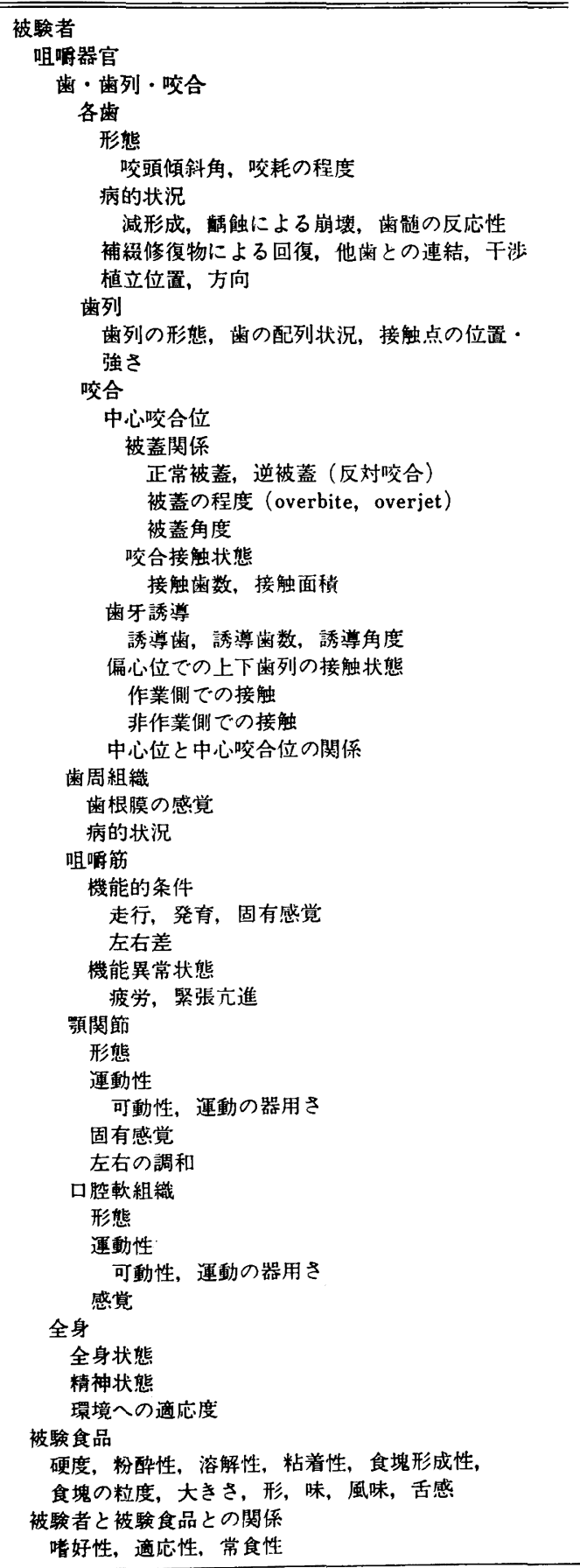

に伴い側方偏位量も増大し，咀罚運動経路が全体的に相 似型に大きくなっていることを示す. しかし， $2.0 \mathrm{~mm}$ 以下のレベルでは，側方偏位量に有意差はみられなかっ た.これから，食品の大きさの影響は，開口度の大きい レベルで現れ，咬頭嵌合位付近には，現れないものと思 われる。

また，咀徱の時期に関してみると，閉口路側方偏位量 の変化は咀礵初期よりもむしろ末期によく現れた，食塊 中の食片が大である間は，咀礵運動は上下的な咬断様の 動きを中心にして行われるため, 側方偏位量の変化は少 なく，末期になり細片化した食品をさらに咀礵するため に側方運動要素の多い罒磨運動が増加し，この際の側方 偏位量に食塊全体の大きさ，すなわち，食品の大きさが 影響するものと考えた.

咀徱周期・咬合相時間・開口相時間・閉口相時間は, 食品の大きさに影響されずほとんど一定であった. しか し, 咀箁が進行すると咀嚼周期・開口相時間は変らず に，咬合相時間が延長し，閉口相時間が短縮した．これ はタクアン咀嚼に関しては食塊が紛砕されていくと閉口 時の抵抗が少なくなり閉口相時間が短縮し，また中心咬 合位付近での睘みしめが増え咬合相時間が延長したもの と思われる。

·食品の固さに関して

有意差は, 1.5, 2.0, $4.0 \mathrm{~mm}$ レベルの閉口路側方偏位 量と閉口相時間に現れた。 ハード・ガムは閉口時に抵抗 があり，㗪み切るのにソフト・ガムよりも咬合力を必要 とし，閉口するのに要する時間も延長している，中心咬 合位付近での閉口路の側方偏位量の増加は，片側上下歯 列間に咬断すべき食塊を保持しながら大きな咬合力を発 揮するには，下靧の側方偏位すなわち上下買同名咬頭の 対向関倸が, 開ロレベル $1.5 \sim 4.0 \mathrm{~mm}$ 付近で必要であ ることを示唆している.

Gibbs ら ${ }^{37)}$ は，食品が固い程，閉口路はより側方にな るためであろうと述べている，また，咀嚼の進行によ り, 開口量は減少し, 咬頭嵌合位での静止時間は延長し たとも述へている，今回，6人とい5比較的少ない被験 者数で研究を行ったが，その結果は Gibbs らと一致し た.

また，今回の研究では，食品の大きさと咀嚼周期等, 変化の現れなかった測定項目もあった. 咀嚼運動の恒常 性に関して，前回報告 ${ }^{38)} し た$ 運動経路に関するものの他 に時間的な要素の恒常性も存在するようである.

各被験者でタクアンの器下に至るまでの咀嚼回数は日 によらず一定しており，咬合相時間・開口相時間・閉口 
相時間・咀嚼周期も安定していた. 今回は計測を行って いないが，臙下直前の食塊の粒子の大きさの分布が，そ れに至るまでの咀嚼回数の違いはあっても, 被験者によ らずほぼ一定であったという報告39) むある.

以上のことから, 咀嚼運動には, 食品に適応して変化 する部分と食品による影響が少なく，その被験者につい て常に同様な運動になる部分とが存在していることが示 唆される. 今回の研究では, 食品の大きさにより, 開口 量と咬頭嵌合位より離れた $4.0 \mathrm{~mm}$ 以上のレベルでの閉 口路側方偏位量の変化がみられ，また固さにより，咬頭 厥合位に比較的近い 1.5, 2.0,4.0 mm レベルでの 側 方 偏位量の変化と, 閉口相時間の変化がみられた。 また咀 嚼周期と開口相時間については恒常性の存在が示唆され た.

\section{文献}

1）瑞森崇弘, 桑原隆男, 西尾公一, 宮内修平, 丸山㴊郎： Sirognathograph とパーソナル・コンピュータにより 構成した下䅡運動記録・解析システム, 下澦運動機能と EMG 論文集, 昭和 58 年度, $169 \sim 174$, 下顎 運動機能と EMG 研究会, 1984.

2）瑞森崇弘, 桑原隆男, 西尾公一, 宮内修平, 丸山剛郎, 山 田広司：下頻運動解析ソフトウェア, 第一回ソフトウェア コンファレンス・プロシーディングス, 190 192, 大阪科 学技術センター, 1985.

3）中沢 勇: 下䫑運動の補釉学的研究 有歯䫟の運動, 口病 誌, $13: 81 \sim 98,1939$.

4) Kurth, L.E. : Mandibular movements in mastication, J.A.D.A., $29: 1769 \sim 1790,1942$.

5) Jankelson, B., Hoffman, G.M. and Hendron, J.A. : The physiology of the stomatognathic system, J.A.D.A., $46: 375 \sim 386,1953$.

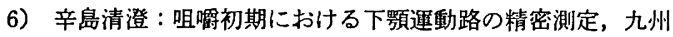
歯会誌, $14: 400 \sim 417,1960$.

7) Shepherd, R.W. : A further report on mandibular movement, Austral. Dent. J., $5: 337 \sim 342,1960$.

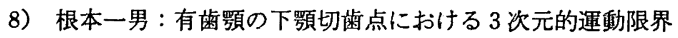
の研究, 補緅誌, $6: 1 \sim 40,1962$.

9) 藍 稔: 切歯点部における咀嚼運動の解析, 補緅誌, $6: 164 \sim 200,1962$.

10) Hickey, J.C., Allison, M.L., Woelfel, J.B., Boucher, C.O. and Stacy, R.W. : Mandibular movements in three dimensions, J. Prosthet. Dent., $13: 72 \sim 92,1963$.

11）大石司朗：アーム型運動分解器とコンデンサー法による下 顎運動の研究 第 2 報 側方滑走運動ならびに咀絗運動の
水平面投影に関寸る考察, 補緅誌, $7: 196 \sim 205,1963$.

12) Beyron, H.: Occlusal relations and mastication in Australian aborigines, Acta Odontol. Scand., 22: 597 678, 1964.

13) Murphy, T.R.: The timing and mechanism of the human masticatory stroke, Arch. oral Biol., $10: 981$ $\sim 993,1965$.

14) Ahlgren, J. : Mechanism of mastication, Acta Odontol. Scand., 24 Suppl. $44: 1 \sim 109,1966$.

15) Atkinson, H.F., Shepherd, R.W. : Masticatory movement and tooth form, Austral. Dent. J., $12: 49 \sim 53$, 1967.

16）戸田外穗：各種食品咀覆時の下頡切歯点の水平面運動の解 析, 歯科医学, $33: 10 \sim 32,1970$.

17) Gibbs, C.H., Messerman, T., Reswick, J.B., Derda, H.J. : Functional movements of the mandible, J. Prosthet. Dent., $26: 604 \sim 6201971$.

18）川村貞行：咀嚼時の下䅡切歯点の前頭面運動について, 歯 科医学, $36: 61 \sim 89,1973$.

19) Gillings, B.R.D., Graham, C.H. and Duckmanton, N.A. : Jaw movements in young adult men during chewing, J. Prosthet. Dent., $29: 616 \sim 627,1973$.

20）田原邦昭：3次元変位計による咀嚼運動の切歯点における 解析, 歯科学報, $74: 1810 \sim 1845,1974$.

21）中島昭彦: 咀謝機能に関与する二, 三の生理学的要因の分 析, 九州歯会誌, $30: 20 \sim 36,1976$.

22）加藤信次 : 顎関節機能障害患者の切歯点における咀嚼運動 について, 齿科医学, $41: 117 \sim 146,1978$.

23）仁科隆実 : 咀嚼運動形式の EMG 的特徵について, 歯科医 学, $42: 1 \sim 27,1979$.

24) Gordon, T.E.Jr. : Alteration of patient chewing patterns after occlusal modification, Quintessence. Int., 10 (3) : $41 \sim 46,1979$.

25) Klineberg, I. : Influences of temporomandibular articulator mechanoreceptors on functional jaw movements, J. oral Rehab., $7: 307 \sim 317,1980$.

26）水野起良廣 : 咬頭嵌 合位付近の咀翻運動経路に関する研 究, 愛院大誌, $17: 259 \sim 283,1980$.

27) Wood, W.W., Gelfant, H., Hannam, A.G. : Effect of occlusal reconstruction on the reproducibility of chewing movements, J. Prosthet., Dent., $46: 181$ 184,1981 .

28）柴田考典：下䫑前突症における頡運動機能に関する研究, 歯科学報, $81: 241 \sim 265,1981$.

29） D.J. ニール，豊田 実, J.K.L. ダレイシャー：食物差が 咀嚼パターンに及ぼす影響について, 神奈川歯学, 17 ： $130 \sim 136,1982$.

30）森 隆司：咀哷運動経路の研究一空口側方滑走運動路およ 
び食品の影響一, 補緅誌, $26: 274 \sim 297,1982$.

31) Hoffman, Von M. and P. Proschel : Unterkieferdynamik und Kaumuster von Totalprothesentragern und Vollbezahnten -Eine Pilotstudie, Dtsch. zahnarztl. Z., $37: 763 \sim 771,1982$.

32）尾崎佳孝：额関節症にみられる䫅運動異常に関する研究, 歯科学報, $83: 937 \sim 980,1983$.

33) Mongini, F., Tempia-Valenta, G.: A graphic and statistical analysis of the chewing movements in function and dysfunction, J. Craniomandib. Prac., $2: 125 \sim 134,1984$.

34）桑原隆男, 瑞森 崇弘, 西尾公一, 宮内修平, 丸山用郎: 下額切歯点の咀礵運 動に関する研究一正常咬合者におい て一, 補緅誌, $29: 106 \sim 115,1985$.

35) Maruyama, T., Kuwabara, T., Nakamura, Y., Akanishi, M., Miyauchi, S. and Kuroda, T.: A new mandibular movement recording and analysing system composed of Sirognathograph and a Personal computer, and its clinical application, J. Osaka Univ. Dent. Sch., $24: 97 \sim 111,1984$.

36）河村洋二郎: 口腔生理学, 159, 永末書店, 京都, 1972.

37) Gibbs, C.H. and Lundeen, H.C. : Jaw movements and forces during chewing and swallowing and their clinical significance; (Lundeen, H.C. and Gibbs, C.H. : Advances on occlusion, 1 st ed., John Wright. PSG Inc., Boston Bristol London), 2 32, 1982.

38）瑞森崇弘, 桑原俊也, 中村康弘, 桑原隆男, 西尾公一, 宮

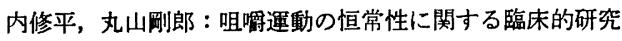
一同一食品における運動経 路について一, 補緅誌, 29 : 647 656, 1985.

39) Jiffry, M.T.M. : Variations in the particles produced at the end of mastication in subjects with different types of dentition, J. oral Rehab., $10: 357 \sim 363,1983$. 